\title{
Fast climatic changes place an endemic Canary Island macroalga at extinction risk
}

 \\ Juan Pedro Díaz ${ }^{4}$ Marta Sansón ${ }^{1}$
}

Received: 11 February 2021 / Accepted: 7 August 2021 / Published online: 29 October 2021

(c) The Author(s) 2021

\begin{abstract}
Global warming and ultraviolet radiation (UVR) affect marine organisms worldwide. However, we still lack knowledge about the consequences of these environmental changes to range-restricted macroalgae species, such as Gelidium canariense, a habitat-forming endemic of the Canary Islands. The aim of this study is to provide useful data for analyzing the conservation status of this endemic species. To do this, (1) we compared distributional data from 1987 with the data collected in 2008 and 2019 along the northern coast of Tenerife; (2) we assessed the variation in macroalgae assemblages dominated by G. canariense over the last decade on this same cost; and (3) we explored the correlation of these results with the actual trends of sea surface temperature (SST), air temperature at $2 \mathrm{~m}$ above the sea surface (T2m), UVR, and downward solar radiation (DSR). The results showed significant changes in the distribution of G. canariense in the last 30 years at Tenerife. More than $90 \%$ of its populations have declined. The endemic macroalgae have been replaced by the globally distributed species Pterocladiella capillacea at nearly all the sites studied. The cover of G. canariense and Gelidium arbuscula decreased significantly with increasing SST and T2m. Additionally, G. canariense is negatively related to the rise in UVR. These results highlight the vulnerability of both species of Gelidium to global warming and UVR, but especially of G. canariense. The drastic decline of this species reveals the need to upgrade its conservation status and implement protection measures to reduce the damage that predicted global change scenario may have to their relict populations.
\end{abstract}

Keywords Canary Islands $\cdot$ Decline $\cdot$ Gelidium $\cdot$ Range-restricted $\cdot$ SST $\cdot$ Ultraviolet radiation

\section{Introduction}

Global warming and ultraviolet radiation (UVR) can affect marine and terrestrial ecosystems worldwide (Myers et al. 2000; Parmesan and Yohe 2003; Schiel et al. 2004; Bischof et al. 2006; Mieszkowska et al. 2006; Hawkins et al. 2009;

Communicated by Wolfgang Cramer

Beatriz Alfonso

balfonso@ull.es

José Carlos Hernández

jocarher@ull.es

Carlos Sangil

carlossangilhernandez@gmail.com

Laura Martín

laura.martin@ieo.es

Francisco Javier Expósito

fexposit@ull.es

Juan Pedro Díaz

jpdiaz@ull.es
Marta Sansón

msanson@ull.es

1 Departamento de Botánica, Ecología Y Fisiología Vegetal, Facultad de Farmacia, Universidad de La Laguna, 38200 Canary Islands, Spain

2 Departamento de Biología Animal, Edafología Y Geología, Facultad de Ciencias, Universidad de La Laguna, Canary Islands, Spain

3 Instituto Español de Oceanografía, Centro Oceanográfico de Canarias, Canary Islands, Spain

4 Departamento de Física, Universidad de La Laguna, Canary Islands, Spain 
Ballaré et al. 2010; Burrows et al. 2011; Morueta-Holme et al. 2015). To countless organisms, the rise in ocean and air temperatures can result in distributional shifts, abundance or density changes, phenological modifications (i.e. migration, flowering, and spawning), morphological changes (i.e. body size), and even genetic frequency shifts (Root et al. 2003; Parmensan and Yohe 2003; Both et al. 2009; La Sorte and Jetz 2010; Casado-Amezúa et al. 2019). Additionally, the effects of UVR may reduce the uptake of atmospheric carbon dioxide in photosynthetic organisms, generate DNA damage, and affect species diversity, ecosystem stability, trophic interactions and global biogeochemical cycles (Häder et al. 2011; Schimitz et al. 2018). Likewise, the negative effects of UVR may be augmented by other environmental changes, including global climate change processes (Bais et al. 2015; Andrady et al. 2017; Barnes et al. 2019).

Species vulnerability to global warming and changes in UVR may depend on both ecological and geographical characteristics (Broennimann et al. 2006) and the ability of organisms to adapt to new conditions, successfully disperse and migrate to existing suitable habitats. Among seaweeds, temperature delimits three different types of essential boundaries: lethal boundaries (i.e., the ability of species to survive unfavorable seasons), growth boundaries (i.e., the temperature range in which species can grow), and reproductive boundaries (i.e., the temperature range suitable for reproduction) (Bartsch et al. 2012; Eggert 2012). These boundaries are generally species-specific; however, characteristics of the ecosystem that the species inhabits play a fundamental role in determining species adaptability. For example, intertidal macroalgae already live in an extremely dynamic environment and are adapted to the stress of emersion, while changes in irradiance and desiccation are more stressful for subtidal species (Bischof et al. 1998; Wiencke et al. 2006). Additionally, the successful dispersal of macroalgae by propagules, such as spores or zygotes, is lower than that in terrestrial plants due to differences in the surrounding environment and motility and viability of their propagules (Santelices 1990; Norton 1992; Gaylord et al. 2002, 2006; Incagnone et al. 2015). Ultimately, the potential of species to adapt to new conditions, together with their dispersal capability, determines their ability to migrate to existing habitats, if available.

Furthermore, the ability of species to withstand environmental changes (e.g., increasing temperature and UVR) will differ between wide-ranging species and range-restricted (endemic) species. The latter live under only limited environmental conditions and would thus struggle more to adapt to new conditions and may disappear when lethal boundaries are exceeded. Marine macroalgal endemism is less common than terrestrial plant endemism. Some endemic marine macroalgae play major roles in certain ecosystems, and during the last decade, studies have focused mainly on the risks that global warming may pose to these species. The direct consequences of rising temperatures for endemic species are, on the one hand, population reductions and even local extinctions (Thibaut et al. 2005; Smale and Wernberg 2013; Buonomo et al. 2018). On the other hand, detrimental effects of warming on early life stages have been reported for several species (Andrews et al. 2014; Wernberg et al. 2016; Capdevila et al. 2019). Additionally, indirect consequences arise when endemic macroalgae are the dominant species in an ecosystem; hence, the loss of habitat-forming species would impact other species of the benthic community (Smale and Wernberg, 2013; Capdevila et al. 2016). In contrast, deleterious effects of UVR on endemic macroalgae have rarely been studied. Only Arctic and Antarctic endemic macroalgae species have been thoroughly studied in relation to increasing UVR (Karsten et al. 2003; Roleda et al. 2007a, b; Houvinen and Gómez 2013; Häder 2018), while the remaining studies have focused on widespread or important commercial macroalgae species (Gomez and Figueroa 1998; Bischof et al. 2006; Navarro et al. 2019; Quintano et al. 2017). Nevertheless, all of the previous studies agree that changes in UVR can shape seaweed communities (e.g., by conditioning the vertical zonation) of macroalgae and that most certainly, early developmental stages are the most vulnerable to the increase in UVR.

Nonetheless, a distinction should be made between continental and island endemic seaweeds. In general, islands are considered gathering places for algae propagules from different biogeographical areas (Sansón et al. 2001), while they are treated as areas of isolation for terrestrial species (Whittaker et al. 2007). However, algae endemic to islands are more susceptible to dying off and eventually result in global extinction because the migration is limited to the island's boundaries. The total number of species on islands is generally lower than that on continents; nevertheless, the high level of endemism in islands at all taxonomic levels highlights their extensive contribution to global biodiversity (Malcolm and Markham 2000; Wilmé et al. 2006; Whittaker and Fernández-Palacios 2007; Kier et al. 2009; Veron et al. 2019). Despite this fact and the inherent vulnerability of islands' endemic macroalgae, studies of the direct or indirect effects of global warming and UVR on these species are scarce. Some studies have focused on short- and longdistance dispersal pathwways of an endemic fucalean species of New Zealand (Buchanan and Zucarello 2012); others have unraveled the extensive cryptic species diversity and the fine-scale endemicity of Portieria species in the Philippine archipelago (Payo et al. 2012). However, we still lack knowledge about the consequences of climate 
change on this kind of vulnerable endemic seaweeds and the indirect implications at the community level after their disappearance.

The Canary Islands $\left(28^{\circ} \mathrm{N}, 16^{\circ} \mathrm{W}\right)$ are an oceanic archipelago situated in the subtropical gyre of the northeastern Atlantic Ocean. The upwelling of cold waters off the coast of northwestern African and the warmer waters from the open ocean influence these islands (Barton et al. 1998; Van den Bogaard 2013). These attributes create a sea surface temperature gradient of almost $2{ }^{\circ} \mathrm{C}$ from the eastern to the western islands of the archipelago (Barton et al. 1998). Ultimately, this generates fringe habitats that hamper species from migrating between islands and makes any dispersion to the nearest continent more difficult. Among the marine flora of the archipelago are approximately 690 algal species (Gallardo et al. 2016), of which approximately $31 \%$ are restricted to the northeastern Atlantic warm-temperate region and only $3 \%$ (i.e., 24 species) are exclusive endemic algae from the Canary Islands (Sansón et al. 2001).

Gelidium canariense is the only endemic and habitatforming macroalga of the archipelago. This rhodophyte is a dominant species in the upper subtidal zone of the northern rocky shores of four central and western islands. According to historical observational data, populations of G. canariense have suffered an extensive decline in recent decades (Martínez et al. 2015); however, no previous studies have supported this observation with accurate data or characterized the relationship of this species with environmental changes. Hence, the goal of this research is to provide useful data for analyzing the status of this species, which is relevant to global biodiversity. In this study, (1) we evaluated changes in the distribution of the endemic macroalga Gelidium canariense during the last 30 years at the northern shore of Tenerife, (2) we determined the variation in macroalgae assemblages dominated by G. canariense over the last decade on this same coast, and (3) we explored whether these changes correlate with the actual trends of some climatic variables in a scenario of global environmental change.

\section{Material and methods}

\section{Study site}

The Canary Islands are a volcanic archipelago constituted by 7 major islands, several smaller islands and islets and several submarine seamounts. The environmental conditions, together with the geographical position of these islands, contribute to the presence of a unique marine flora. Species of Gongolaria, Ericaria, Cystoseira, Dictyotales, Gelidiales, geniculate coralline algae (GCA), and crustose coralline algae (CCA) and a mix of turf-forming species compose the main macroalgae assemblages on the rocky shores of the archipelago (Sangil et al. 2012, 2018). The only habitatforming endemic species in the archipelago is Gelidium canariense (Alfonso et al. 2019). This perennial red alga inhabits only the upper limit of the subtidal zone along the northern shores of four islands: La Palma, La Gomera, Tenerife, and Gran Canaria. Due to its restricted distribution and observed reductions in its populations, $G$. canariense has been recently classified as a vulnerable species in the List of Wild Species under Special Protection Regime and Spanish Catalog of Threatened Species (Orden TEC/596/2019, BOE 2019). The study area is located on the northern rocky shore of Tenerife, where the largest populations of $G$. canariense are found. This species occurs mainly with the two other habitat-forming Gelidiales: Pterocladiella capillacea and Gelidium arbuscula, which usually grow in greater abundance just above G. canariense.

\section{Historical changes in distribution}

The first data on the spatial distribution of assemblages dominated by Gelidium canariense were documented by Wildpret et al. (1987) as part of a broader characterization of the marine macroalgae communities in the Canary Islands. Subsequently, Rodríguez et al. (2008) provided distributional data, adding coverage data of the assemblages dominated by G. canariense. For the current study, we randomly selected 3 sites in the former distribution of G. canariense in Tenerife (Buenavista, Garachico, and Puerto de la Cruz) (Fig. 1). The presence and absence of $G$. canariense was recorded along a minimum of $2 \mathrm{~km}$ per site. The total distribution obtained was divided into sections of $100 \mathrm{~m}$ in length at each site and compared among years. The data were collected using MapitGIS (spatial asset collection, GPS surveys, and data management for android) and exported into the free and open source Geographic Information System QGIS. The results are expressed as the average extension in meters per section \pm SE.

\section{Macroalgae assemblage variation}

To evaluate the variation over the last decade in assemblages dominated by $G$. canariense, the percentage of cover of all macroalgae species was estimated in 2017 and 2019 at six of the sites previously studied by Rodríguez et al. (2008) in Tenerife (Buenavista, Los Silos, Garachico, El Guincho, San Juan, and Puerto de la Cruz) (Fig. 1). To achieve comparable data sets between years, the same methodology used in Rodríguez et al. (2008) was followed. However, to obtain a better representation of these assemblages and to improve the long-term monitoring program, in 2017 and 2019, we surveyed a total of 6 transects of $10 \mathrm{~m}$ and 3 photocuadrats of $50 \times 50 \mathrm{~cm}$ per transect along the G. canariense belt per 
Fig. 1 Study areas on the north shore of Tenerife (Canary Islands, NE Atlantic). Underlined sites indicate areas where historical distribution was assessed $(\mathrm{Bu}=$ Buenavista, $\mathrm{Ga}=$ Garachico and $\mathrm{Pu}=$ Puerto de la Cruz). Variation in macroalgae assemblages was studied at all sites $(\mathrm{Bu}, \mathrm{Si}=\mathrm{Los}$ Silos, Ga, Gui =El Guincho, $\mathrm{Sa}=$ San Juan and $\mathrm{Pu}$ ). Climatic variables data were obtained for the blue square grid off the north coast of Tenerife



site, instead of 3 transects as performed in Rodríguez et al. (2008). The percentage of cover of the different macroalgae species in each photoquadrat was obtained using the open source image processing program ImageJ. To minimize differences between years and prevent misidentifications, some species were aggregated into genera or, corresponding to morphological classifications, turf-forming species, crustose coralline algae (CCA), geniculate coralline algae (GCA), and cyanobacteria, according to Littler and Littler (1980). We defined turf-forming species as sparse to thick mats of diminutive and juvenile algae that are $<2 \mathrm{~cm}$ tall (Littler and Littler 2011).

\section{Climatic variables}

Monthly averages for the period 1979-2018 of sea surface temperature (SST), air temperature at $2 \mathrm{~m}$ above the surface of the seawater ( $\mathrm{T} 2 \mathrm{~m})$, downward UV radiation at the surface (UVR), the amount of ultraviolet radiation reaching the surface with a wavelength of $0.20-0.44 \mathrm{~nm}$, and downward solar radiation (DSR) the amount of solar radiation (i.e., shortwave radiation) that reached the surface, corresponding to the northern shore of Tenerife Island were obtained from the Copernicus Climate Change Service (European Commission) with a horizontal grid resolution of $0.25^{\circ} \times 0.25^{\circ}(\mathrm{Fig}, 1)$. These data correspond to ERA5, the last climate reanalysis dataset produced by the European Centre for Medium Range
Weather Forecasts (ECMWF, https://www.ecmwf.int). The reanalysis data combine observations from across the world with model data. This combination permits us to estimate biases between observations and produce data where in situ coverage is low. One of the novelties in the ERA5 dataset is the estimation of uncertainty using the 10-member data assimilation (EDA) system. Although the reanalysis data from ERA-5 are designed for global studies, the only meteorological station located at the study site is situated $2000 \mathrm{~m}$ above sea level (Izaña Atmospheric Research Centre-AEMET); hence, we considered the data from ERA-5 very useful in the absence of any other available source to obtain long-term climatic variables at sea level.

\section{Data analysis}

Historical changes in the distribution of $G$. canariense were analyzed by performing a permutational analysis of variance (ANOVA) (Anderson et al. 2008) with a two-factor design that included "year" (random, 3 levels) and "site" (random, 3 levels). Likewise, a permutational ANOVA was used to test the variability in the macroalgae in assemblages dominated by $G$. canariense among years and sites. The design included two factors: "year" (random, 3 levels) and "site" (random, 6 levels). Both analyses were performed on a Bray-Curtis similarity matrix calculated on square-root transformed data. Because the design of the assemblage 
Table 1 Permutational analysis of variance (ANOVA) of the distribution of Gelidium canariense in the north shores of Tenerife, with factors 'year' (random, 3 levels) and 'site' (random, 3 levels)

\begin{tabular}{lrrrcl}
\hline Source & df & \multicolumn{1}{l}{ SS } & MS & Pseudo- $F$ & P(perm) \\
\hline year & 2 & 92427 & 46213 & 1.761 & 0.29 \\
site & 2 & 50249 & 25125 & 0.942 & 0.434 \\
year $\times$ site & 4 & 106000 & 26652 & 18.23 & 0.000 \\
Residual & 243 & 355000 & 1462 & & \\
Total & 251 & 620000 & & & \\
\hline
\end{tabular}

variation analysis was unbalanced, to obtain more power, the total number of samples from 2017 and 2019 at each site $(n=18)$ was randomly reduced to half $(n=9)$, and the same statistical analysis was performed again. If different results were obtained, this would point out that differences in the number of replicates between years affected the analysis. This was done three times with three different sets of random samples. To identify the macroalgae species that contribute most to the variability among "years" and "sites," a SIMPER analysis was performed. All the statistical analyses were performed using PRIMER 7 and PERMANOVA + (Anderson et al. 2008) software and statistical package.

The temporal trend of each climatic variable was evaluated by calculating the linear regression of the anomalies of each variable versus the time for the total period per year. The climatic variables with significant regressions were related to the cover values of the macroalgae species that contributed most to shifts in the last decade, according to the SIMPER analysis. The analysis was performed with the IBM SPSS 26 statistical package.

\section{Results}

\section{Historical changes in distribution}

The distribution of Gelidium canariense has changed significantly over the last 3 decades (Table 1) at the north rocky shores of Tenerife. Puerto de la Cruz, the populations of which occupied the entire coastline in 1987,

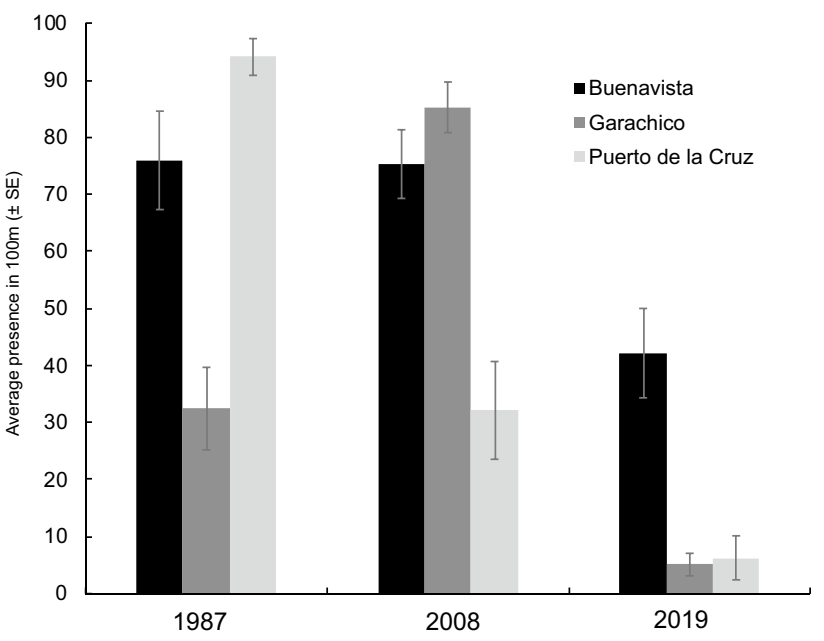

Fig. 2 Average presence (meters \pm SE) of Gelidium canariense along a transect of $100 \mathrm{~m}$ examined at each site and year. Significant interaction of site and year was obtained in the permutational ANOVA analysis

suffered the greatest decline in G. canariense extension, with average reductions from $94.07 \mathrm{~m} \pm 3.21 \mathrm{~m}( \pm \mathrm{SE})$ to $6.32 \mathrm{~m} \pm 3.85$ over $100 \mathrm{~m}$ of coast, which corresponded to a $93 \%$ reduction in the previous distribution. Similarly, at Garachico, the decrease in the population ranged from $32.47 \mathrm{~m} \pm 7.22$ to $5.13 \pm 1.97$, for a loss of $84 \%$ of the original population. Finally, Buenavista currently harbors the most extensive distribution. In this location, the decrease in the population ranged from $75.95 \mathrm{~m} \pm 8.62$ to $42.17 \mathrm{~m} \pm 7.83$, which corresponds to a reduction of $45 \%$ of the former populations. The results also show that the greatest changes in populations along the island have taken place over the last decade (Fig. 2) and that the populations that remain are conserved as fragmented populations.

\section{Macroalgae assemblage variation}

The analysis of macroalgae species in the assemblages dominated by $G$. canariense shows significant variation in
Table 2 Permutational analysis of variance (ANOVA) of the percentage of cover of macroalgae in Gelidium canariense assemblages, with factors 'year' (random, 3 levels) and 'site' (random, 6 levels)

\begin{tabular}{lrcccc}
\hline \multicolumn{2}{l}{ Permutational ANOVA } & & & & \\
\hline Source & df & SS & MS & Pseudo-F & P(perm) \\
\hline year & 2 & 32924 & 16462 & 5.110 & 0.002 \\
site & 5 & 46389 & 9277.8 & 4.089 & 0.000 \\
year $\times$ site & 10 & 32211 & 3221.1 & 4.112 & 0.000 \\
Residual & 216 & 169100 & 783.19 & & \\
Total & 233 & 353000 & & & \\
\hline
\end{tabular}


Table 3 SIMPER analysis of species that contribute up to the $70 \%$ of the dissimilarity among levels of factors 'year' and 'site'. CCA, crustose coralline algae; GCA, geniculate coralline algae; G. arb. Gelidium arbusculum; G. can, Gelidium canariense; P. cap, Pterocladiella capillacea; Turf, turf-forming species. * Denotes species that contribute more than $60 \%$ of the dissimilarities among groups of 'year' and 'site'. Bu, Buenavista; Si, Los Silos; Ga, Garachico; Gui, El Guincho; $\mathrm{Sr}$, San Juan; Pu, Puerto de la Cruz

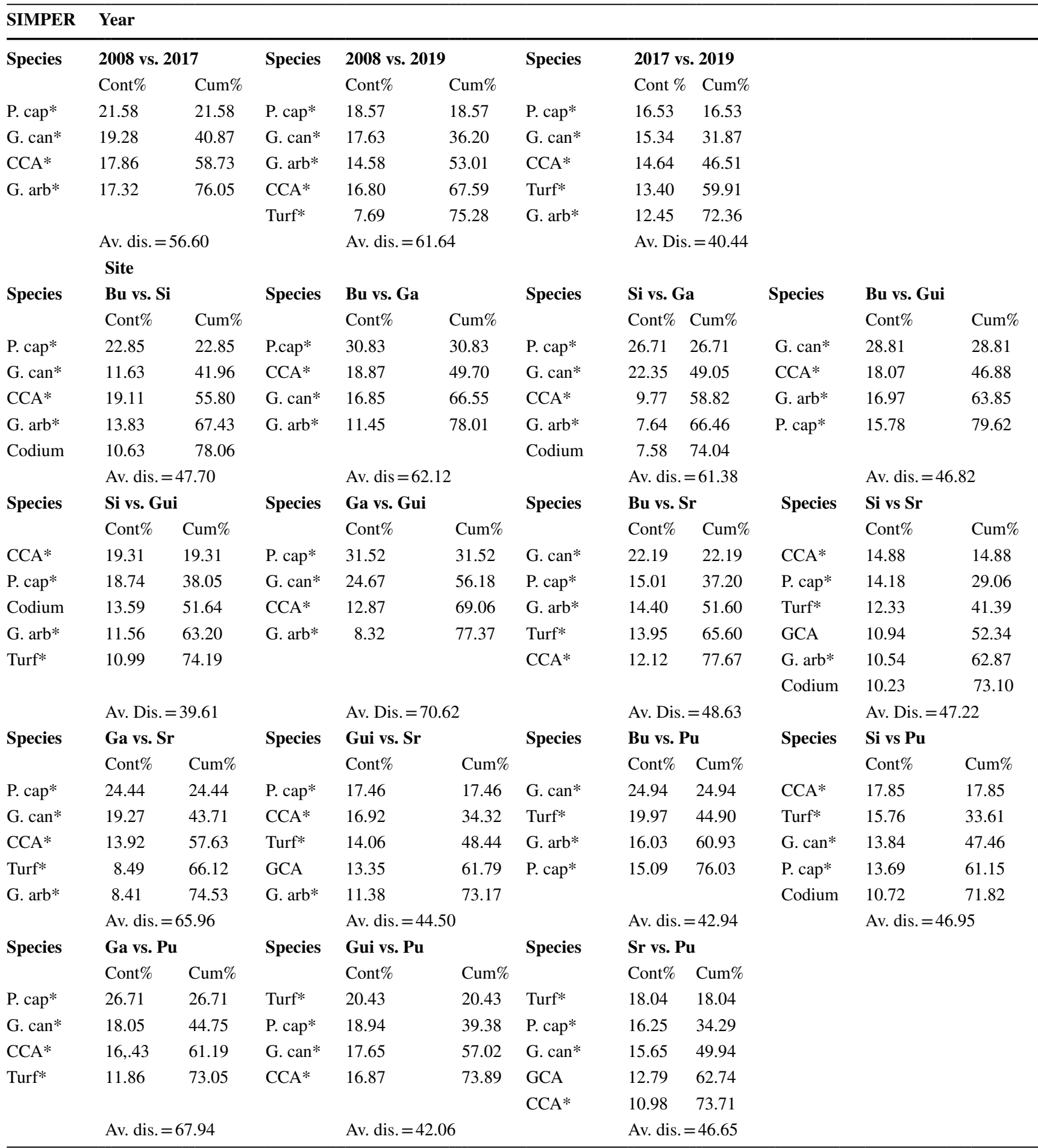

the interaction term of the random factors ("year $\times$ site") (Table 2). The percentage of macroalgae cover has significantly changed in the last decade. The SIMPER analysis revealed that $G$. canariense, G. arbuscula, $P$. capillacea, coralline crustose algae (CCA), and turf-forming species explain more than $60 \%$ of the total spatial and temporal variation in macroalgae species cover (Table 3). In 2008, G. canariense was the dominant species in Los Silos, 
Garachico, and San Juan, with a mean percentage cover $( \pm$ SE) of $57.22 \pm 9.63,46.22 \pm 8.12$, and $36.11 \pm 14.28$, respectively. Ten years later, this endemic species had almost disappeared in Los Silos $(1.68 \pm 0.85 \%)$ and San Juan $(9.97 \pm 3.69 \%)$, whereas in Garachico, $60 \%$ of the species cover remained. The small population of $G$. canariense documented in El Guincho in 2008 disappeared completely in 2017. G. arbuscula was the dominant species in Buenavista $(60.55 \pm 9.34 \%)$ and El Guincho $(17.77 \pm 2.42)$, although it has drastically declined in the last decade at both sites (Buenavista: $17.14 \pm 4.63 \%$ in 2017 and $3.57 \pm 1.71 \%$ in 2019 ; El Guincho: $2.36 \pm 1.72$ in 2019). In 2008, Pterocladiella capillacea was the dominant species in assemblages of Puerto de la Cruz only, but since 2017, it has become the dominant species at all studied sites of the island, with abundances above $50 \%$, except for Garachico, where abundances have remained low. CCA only contributed to the macroalgae assemblages in San Juan and Puerto de la Cruz in 2008, while in the last decade, they have become an important contributor in Garachico $(21.46 \pm 3.67 \%)$, El Guincho $(18.45 \pm 4.11 \%)$, Los Silos $(3.13 \pm 0.93 \%)$, and Buenavista $(3.59 \pm 2.51 \%)$. Similarly, turf-forming species were not present 10 years ago; however, they are currently inhabiting all sites of the island, with the highest abundances in San Juan $(18.04 \pm 3.52 \%)$ and Puerto de la Cruz $(11.78 \pm 3.77 \%)$ and the lowest in Los Silos (2.25 $\pm 0.82 \%)$ and Buenavista $(0.023 \pm 0.02 \%)$ (Table 4; Figs. 3 and 4).

\section{Importance of climatic variables to macroalgae assemblage variation}

The SST, T2m, and UVR have increased significantly over the last 40 years off the northern coast of Tenerife. SST and $\mathrm{T} 2 \mathrm{~m}$ have risen $0.2{ }^{\circ} \mathrm{C}$ per decade, whereas UVR has increased $0.1 \mathrm{~W} / \mathrm{m}^{2}$ per decade. DSR has shown no significant differences over the last 4 decades (Fig. 5). For the Gelidium species, the relationships of the mean percentage of cover to the climatic variables show significant linear regressions. The cover of G. canariense decreased significantly in the last decade in parallel with the increase in SST, T2m, and UVR (Fig. 6a), whereas the reduction in cover of G. arbuscula is related to rises in SST and T2m (Fig. 6b). Regarding P. capillacea, no significant relationship with the climatic variables was observed (Fig. 6c), despite having an evident increase of nearly $30 \%$ in cover in the last decade. The CCA and turf-forming species did not show significant changes with the trends of the climatic variables (Figs. 6d and e).

\section{Discussion}

For the first time, the reduction in the population of a macroalga endemic to oceanic islands over the last 30 years is demonstrated. This study revealed a negative correlation between the cover of the endemic and habitat-forming species G. canariense from the Canary Islands, the global warming and the increase in ultraviolet radiation over the last decade in Tenerife Island. Furthermore, the results show that indirect consequences of its decrease have resulted in changes at the assemblage level, creating available niche space for $P$. capillacea to proliferate and causing local extinctions at some sites within its range of distribution in this island.

Temperature is a major factor controlling the rate of photosynthesis and growth in all plants and algae (Davison 1991; Clark et al. 2013), and in G. canariense and G. arbuscula, the results suggest that rising air and ocean temperatures are important factors determining their presence and cover in the archipelago. These species inhabit the upper limit of the subtidal zone, so they are exposed to air during low tides and are submerged under the surface of the water for the rest of the time (Polifrone et al. 2012; Alfonso et al. 2017, 2019). Consequently, their decrease in cover with the rise in SST and T2m suggest that the species are sensitive to warming and that are vulnerable to changes in seawater but also air temperature during emersion periods. In fact, previous experimental studies have demonstrated the relation of the vertical zonation of these species to their low tolerance to emersion (Domínguez-Álvarez et al. 2011).

In addition, increasing UVR was negatively correlated with a significant decrease only in $G$. canariense cover. This endemic species grows only in the northern rocky shores of La Palma, La Gomera, Tenerife, and Gran Canaria islands, where there is the greatest accumulation of clouds carried by trade winds (Martin et al. 2011). Mercado et al. (2001) demonstrated that the photosynthetic rate of this species might be limited by incident light. This could suggest an adaptation to a narrow and species-specific level of UVR and would explain why this endemic species grows on only the northern rocky shores of the islands, while the other two habitat-forming Gelidiales species can grow along the coasts throughout the archipelago. It has been determined that in many macroalgae, the most UV-susceptible life stages are their propagules (Roleda et al. 2007a, b; Wiencke and Amsler 2012; Navarro et al. 2016, 2019). Hence, the finding that UVR was only negatively correlated with the endemic species cover, may suggest not only an adaptation of the adults of this species to its habitat but also the vulnerability of its early life stages to changes in this parameter. 
Table 4 Mean percentage cover of macroalgae $(\% \pm$ SE) registered in each year and site at Tenerife

\begin{tabular}{|c|c|c|c|c|c|c|c|}
\hline & Species & Buenavista & Los Silos & Garachico & El Guincho & San Juan & Puerto Cruz \\
\hline \multirow[t]{14}{*}{2008} & Rhodophyta & & & & & & \\
\hline & Corallina sp. & - & - & - & $13.33 \pm 0.00$ & - & - \\
\hline & Crustose coralline algae & $2.22 \pm 1.47$ & - & - & - & $20.00 \pm 10.71$ & $13.89 \pm 3.89$ \\
\hline & Gelidium arbuscula & $60.55 \pm 9.34$ & $6.89 \pm 1.56$ & $4.11 \pm 0.55$ & $17.77 \pm 2.42$ & $22.22 \pm 2.22$ & $18.78 \pm 4.47$ \\
\hline & Gelidium canariense & $26.66 \pm 6.94$ & $57.22 \pm 9.63$ & $46.22 \pm 8.12$ & $2.22 \pm 0.55$ & $36.11 \pm 14.28$ & $21.66 \pm 3.46$ \\
\hline & Laurencia sp. & $7.22 \pm 7.22$ & - & - & - & - & - \\
\hline & $\begin{array}{l}\text { Pterocladiella capillacea } \\
\text { Phaeophyceae }\end{array}$ & - & $15.00 \pm 0.96$ & $5.55 \pm 3.88$ & $14.44 \pm 4.01$ & $18.89 \pm 1.11$ & $35.55 \pm 5.88$ \\
\hline & Halopteris scoparia & $2.77 \pm 2.77$ & - & - & - & - & - \\
\hline & Sargassum sp. & - & - & - & - & - & $0.55 \pm 0.55$ \\
\hline & Gongolaria abies-marina & - & - & $0.33 \pm 0.33$ & - & - & - \\
\hline & Chlorophyta & & & & & & \\
\hline & Codium sp. & - & $1.11 \pm 1.11$ & - & $1.11 \pm 0.55$ & - & - \\
\hline & Ulva sp. & - & - & - & - & $0.33 \pm 0.33$ & $7.22 \pm 4.33$ \\
\hline & Cyanobacteria & - & - & - & $2.22 \pm 2.22$ & & \\
\hline \multirow[t]{19}{*}{2017} & Rhodophyta & & & & & & \\
\hline & Corallina sp. & $0.36 \pm 0.35$ & - & - & - & $3.51 \pm 1.66$ & $2.83 \pm 2.38$ \\
\hline & Crustose coralline algae & $4.78 \pm 3.14$ & $20.70 \pm 3.27$ & $29.42 \pm 5.28$ & $6.12 \pm 1.45$ & $9.87 \pm 2.98$ & $1.44 \pm 0.58$ \\
\hline & Gelidium arbuscula & $17.14 \pm 4.63$ & $2.87 \pm 0.70$ & $6.22 \pm 2.19$ & - & $5.71 \pm 2.02$ & $3.01 \pm 1.36$ \\
\hline & Gelidium canariense & $22.90 \pm 6.03$ & $2.15 \pm 1.53$ & $42.42 \pm 6.62$ & - & $9.97 \pm 3.69$ & $12.38 \pm 4.46$ \\
\hline & Grateloupia imbricata & - & - & $0.02 \pm 0.02$ & - & - & - \\
\hline & Laurencia sp. & - & $0.85 \pm 0.27$ & - & $0.15 \pm 0.15$ & $2.47 \pm 1.03$ & $1.73 \pm 1.34$ \\
\hline & Pterocladiella capillacea & $51.36 \pm 4.78$ & $48.22 \pm 5.12$ & $3.72 \pm 2.03$ & $78.86 \pm 4.77$ & $54.60 \pm 6.52$ & $52.65 \pm 6.80$ \\
\hline & Phaeophyceae & & & & & & \\
\hline & Sargassum sp. & - & - & $0.39 \pm 0.21$ & - & - & - \\
\hline & Padina pavonica & - & - & $0.004 \pm 0.004$ & - & - & - \\
\hline & Chlorophyta & & & & & & \\
\hline & Anadyomene saldanhae & - & $0.02 \pm 0.2$ & - & - & - & - \\
\hline & Chaetomorpha sp. & - & $0.03 \pm 0.02$ & - & - & - & - \\
\hline & Cladophora sp. & - & - & - & - & $0.007 \pm 0.007$ & - \\
\hline & Codium sp. & $0.02 \pm 0.02$ & $5.20 \pm 1.37$ & $0.34 \pm 0.21$ & - & - & - \\
\hline & Ulva sp. & - & $0.20 \pm 0.09$ & $0.08 \pm 0.03$ & - & - & - \\
\hline & Cyanobacteria & - & $0.39 \pm 0.35$ & $0.60 \pm 0.28$ & $0.37 \pm 0.22$ & $1.03 \pm 0.56$ & $0.04 \pm 0.04$ \\
\hline & Turf & $0.61 \pm 0.44$ & $3.32 \pm 1.28$ & $1.04 \pm 0.33$ & $3.50 \pm 1.73$ & $4.95 \pm 0.79$ & $18.33 \pm 5.56$ \\
\hline \multirow[t]{16}{*}{2019} & Rhodophyta & & & & & & \\
\hline & Asparagopsis taxiformis & - & - & - & - & $0.11 \pm 0.11$ & - \\
\hline & Corallina sp. & - & - & $3.22 \pm 3.22$ & - & $14.89 \pm 4.73$ & $0.11 \pm 0.08$ \\
\hline & Crustose coralline algae & $3.59 \pm 2.41$ & $13.43 \pm 3.44$ & $21.46 \pm 3.67$ & $18.45 \pm 4.11$ & $4.62 \pm 1.85$ & $3.13 \pm 0.93$ \\
\hline & Gelidium arbuscula & $3.57 \pm 1.71$ & $5.22 \pm 1.93$ & $5.54 \pm 1.35$ & $2.36 \pm 1.72$ & $5.71 \pm 1.88$ & $2.05 \pm 1.43$ \\
\hline & Gelidium canariense & $23.19 \pm 5.13$ & $1.68 \pm 0.85$ & $27.57 \pm 5.66$ & - & $3.01 \pm 1.40$ & $10.42 \pm 4.23$ \\
\hline & Grateloupia imbricata & - & - & $7.11 \pm 1.87$ & - & - & $0.09 \pm 0.09$ \\
\hline & Laurencia sp. & $0.05 \pm 0.05$ & $2.89 \pm 1.14$ & $0.07 \pm 0.70$ & - & $5.12 \pm 2.67$ & $0.69 \pm 0.32$ \\
\hline & Pterocladiella capillacea & $69.06 \pm 4.48$ & $58.01 \pm 6.23$ & $5.36 \pm 1.82$ & $58.81 \pm 6.30$ & $38.92 \pm 6.13$ & $59.53 \pm 5.49$ \\
\hline & Rhodymenia sp. & $0.11 \pm 0.11$ & $0.28 \pm 0.28$ & - & - & $0.04 \pm 0.04$ & $0.95 \pm 0.66$ \\
\hline & Phaeophyceae & & & & & & \\
\hline & Gongolaria abies-marina & - & - & $0.26 \pm 0.26$ & - & - & - \\
\hline & Sargassum sp. & - & - & $1.71 \pm 1.71$ & - & - & - \\
\hline & Colpomenia sinuosa & - & - & $0.03 \pm 0.03$ & - & - & - \\
\hline & Chlorophyta & & & & & & \\
\hline & Chaetomorpha sp. & - & $0.12 \pm 0.06$ & - & $0.002 \pm 0.002$ & $0.01 \pm 0.01$ & $0.01 \pm 0.01$ \\
\hline
\end{tabular}


Table 4 (continued)

\begin{tabular}{lcccccc}
\hline Species & Buenavista & Los Silos & Garachico & El Guincho & San Juan & Puerto Cruz \\
\hline Codium sp. & - & $5.77 \pm 1.67$ & $0.19 \pm 0.16$ & - & $0.01 \pm 0.01$ \\
Ulva sp. & - & $0.07 \pm 0.03$ & $0.18 \pm 0.10$ & $0.02 \pm 0.01$ & $0.08 \pm 0.05$ & $0.04 \pm 0.02$ \\
Valonia utricularis & - & - & - & - & $0.12 \pm 0.10$ & $0.01 \pm 0.01$ \\
Cyanobacteria & $0.01 \pm 0.01$ & $7.18 \pm 1.99$ & $12.51 \pm 3.89$ & $9.71 \pm 2.96$ & $2.95 \pm 1.55$ & $4.50 \pm 2.11$ \\
Turf & $0.02 \pm 0.02$ & $2.25 \pm 0.82$ & $6.36 \pm 2.87$ & $3.61 \pm 1.02$ & $18.04 \pm 3.52$ & $11.78 \pm 3.77$ \\
\hline
\end{tabular}

Changes in species distribution are a worldwide phenomenon under current global warming conditions. The southern limits of several fucalean species, such as Himanthalia elongata, Fucus serratus, and F. vesiculosus, have already shifted to cooler latitudes due to the increase in SST (Duarte et al. 2013; Nicastro et al. 2013). The endemic continental Mediterranean species Carpodesmia amentacea and $C$. zosteroides have exhibited population reductions and even local extinctions (Thibaut et al. 2005; Buonomo et al. 2018), and the large fucoid Scytothalia dorycarpa, endemic in the temperate regions of southern Australia, experienced poleward contraction after a heat wave event (Smale and Wernberg 2013). Similarly, the distribution of $G$. canariense has been reduced by more than $90 \%$ in only 30 years in Tenerife, and observational recordings suggest the same for the
Fig. 3 Average percentage of cover $(\% \pm \mathrm{SE})$ of the species that contributed more than $60 \%$ to the spatial (six localities) and temporal (three years) variability of the macroalgae assemblages according to the SIMPER analysis. CCA, coralline crustose algae; Turf, turf-forming algae
Buenavista
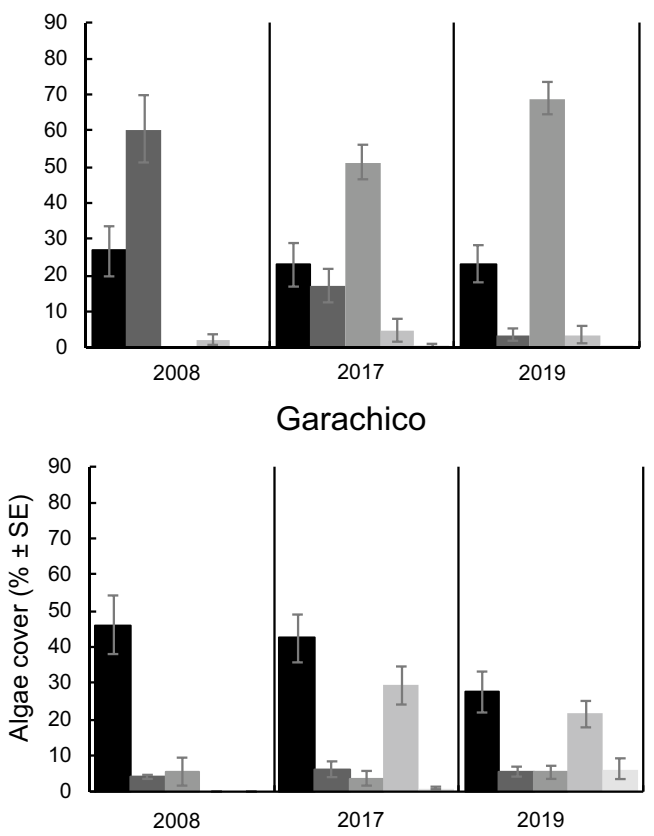

San Juan

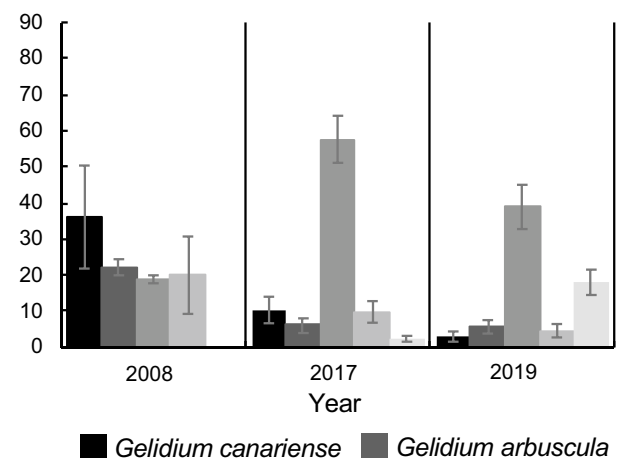

Los Silos



El Guincho



Puerto de la Cruz




Fig. 4 Comparison between 2008 and 2019 of the average percentage of cover of the species that contributed more than $60 \%$ to the spatial and temporal variability of the macroalgae assemblages according to the SIMPER analysis (Gelidium canariense, Gelidium arbuscula, Pterocladiella capillacea, coralline crustose algae (CCA) and turf-forming species) at all sites


other islands. Currently, the greatest populations of this species, at the westernmost site of the island, represent only $45 \%$ of its former distribution. However, contrary to endemic continental macroalgae, it is unfeasible for this species to migrate. On the one hand, it is impossible for propagules to drift northward, where other Macaronesian archipelagos are located, against the Canary current. On the other hand, the temperature of the African upwelling waters is markedly lower than that of Canarian waters, and the sediments that predominate along the coasts of the African upwelling complicate the settlement of propagules. Thus, as having a narrow geographic range is one of the greatest extinction risk factors for many species (Lambers 2015), it is a matter of time before localized impacts or environmental changes, such as increasing temperature or UVR, cause the global extinction of this habitat-forming endemic macroalga from these oceanic islands.

Additionally, significant shifts in the presence or abundance of a habitat-forming macroalga species may lead to indirect effects on the associated benthic organisms. Different kinds of studies, including those with experimental conditions (Schiel and Lilley, 2011; Flukes et al. 2014; Álvarez-Losada et al. 2020), extreme 

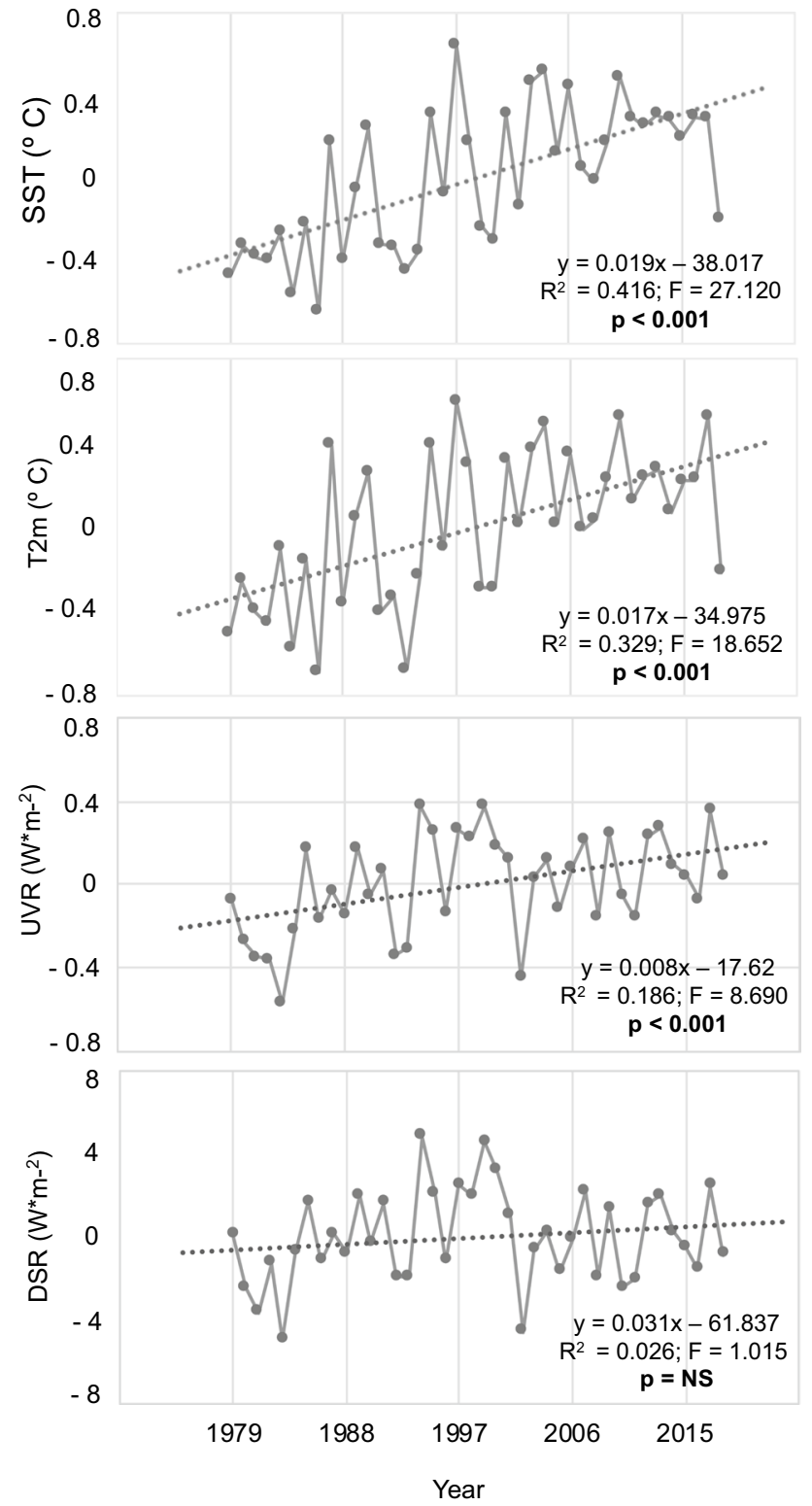

Fig. 5 Linear regression of SST (sea surface temperature), T2m (temperature $2 \mathrm{~m}$ above sea surface), UVR (downward ultraviolet radiation) and DSR (downward solar radiation) anomalies with time for the period 1979-2018. The linear trend equation, $R^{2}, F$-statistic and $p$ values are provided for each variable. NS, no significant

events (Smale and Wernberg, 2013; Borja et al. 2018), and continuous environmental changes (Díez et al. 2012; Tanaka et al. 2012), have shown that warming favors turf-forming algae over habitat-forming species. In southern Australia, the significant reduction in $S$. dorycarpa after an extreme heat wave occasioned deleterious effects on the encrusting coralline algae and sponges, which were favored in the canopy, while turf-forming species proliferated significantly (Smale and Wernberg 2013). In G. canariense assemblages, we detected that over the last 10 years, the cover of CCA and turf-forming species has increased. We would like to point out here that in G. canariense assemblages, CCA are foundation species(Pinedo and Afonso-Carrillo 1994; Muñoz et al. 2007); therefore, CCA cover may have been underestimated in previous studies, when $G$. canariense assemblages were bushy. On the other hand, turf-forming species are considered tolerant to certain levels of environmental changes (Bertolini 2019), as highlighted in previous paragraphs.

The reduction in the dominant species ( $G$. canariense and G. arbuscula) in Tenerife has mainly resulted in a free niche that is occupied by the cosmopolitan red alga Pterocladiella capillacea, currently the most abundant species in most of the northern exposed coasts of the islands. It is important to indicate that the positive relationship of $P$. capillacea with SST, T2m, and UVR is markedly steep despite the absence of significance. This may be due to the similar cover data obtained in the 2017 and 2019 surveys, which masked the real relationship with the climatic variables. Nevertheless, this generalist species exhibits fast growth and high reproductive potential under a wide range of environmental conditions (Guiry and Guiry 2020), which makes it a strong competitor against Gelidium species.

In conclusion, the decline observed in assemblages of G. canariense and G. arbuscula is negatively correlated to environmental variables related to climate change. An increase in SST and $\mathrm{T} 2 \mathrm{~m}$ of $0.2{ }^{\circ} \mathrm{C}$ per decade is significantly correlated with the regression of the cover of both species. Consequently, this regression has left their niche available for $P$. capillacea to proliferate. Moreover, the rise in UVR is negatively correlated with the cover of $G$. canariense over the last decade. Although experimental studies are needed to determine the direct effects of these climatic variables on the species, the results of this study show the susceptibility of both species of Gelidium to global warming and especially highlight the disadvantage of G. canariense, revealing the need to upgrade the conservation status of this species. Understanding the spatiotemporal population trends of endemic macroalgae from oceanic islands, which grow and reproduce within narrow environmental and spatial boundaries, is crucial for predicting the future of many other species affected by the current climatic scenario, and it leads to an urgent call for marine biodiversity managers to implement conservation measures of these habitat-forming species. 


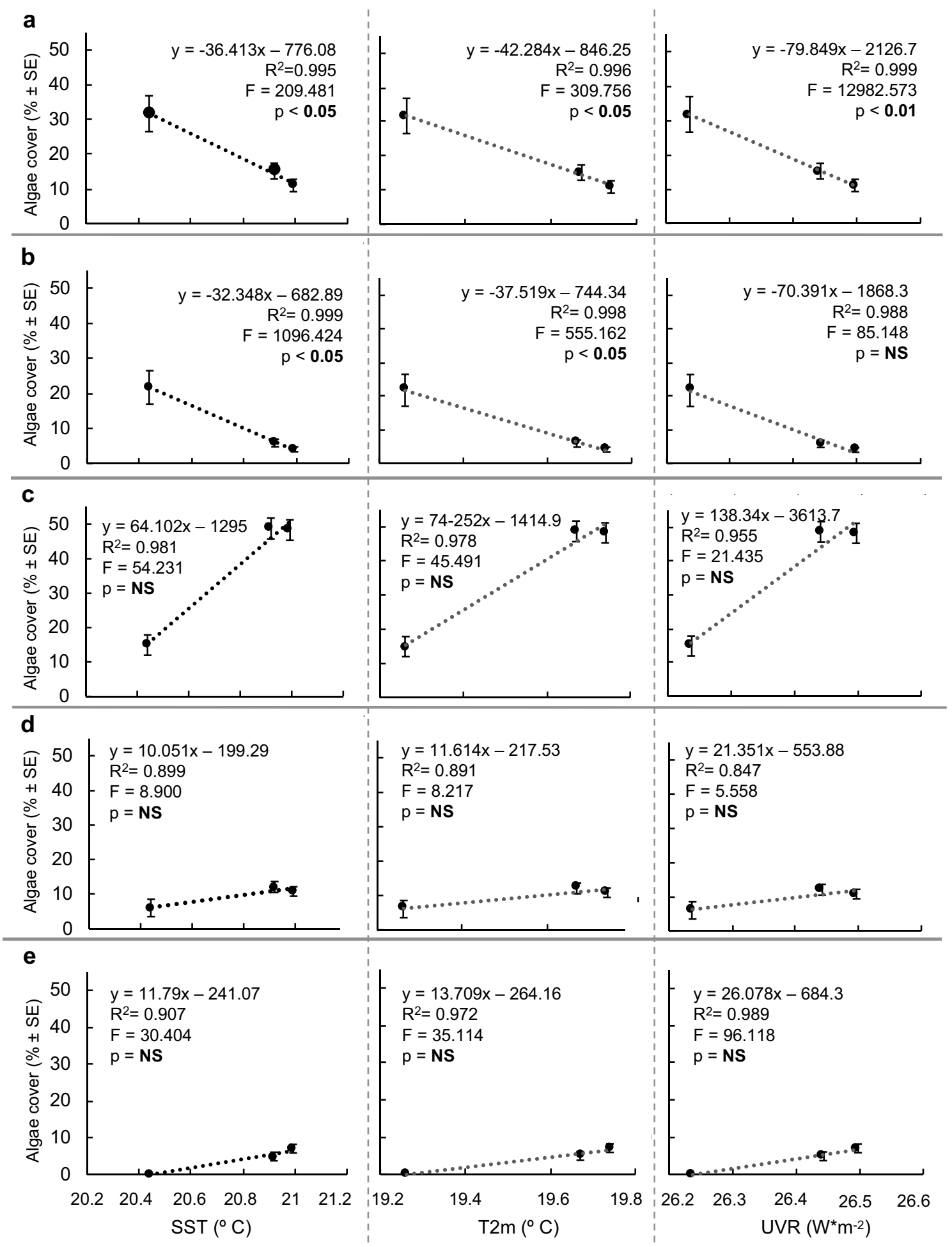

Fig. 6 Correlation of the percentage of cover of the species that contributed more than $60 \%$ to the variability of the macroalgae assemblages among sites and years: A Gelidium canariense, B G. arbuscula, $\mathbf{C}$ Pterocladiella capillacea, D coralline crustose algae (CCA) and $\mathbf{E}$ turf-forming species, with the climatic variables with significant increment for the period 1979-2018 (SST, sea surface temperature; T2m, temperature $2 \mathrm{~m}$ above sea surface; UVR, downward ultraviolet radiation). NS, no significant 
Acknowledgements This work has been possible thanks to the $\mathrm{PhD}$ agreement between Universidad de La Laguna and the funding entity CajaSiete granted to B. Alfonso. We would like to acknowledge Dr. M. Anderson for statistic recommendation to improve the statistical analysis. The members of the Grupo de Observación de la Tierra y la Atmósfera thank to the PLANCLIMAC Project (MAC/3.5b /244) for its support. We thank all the institutions involved in generating the ERA5 reanalysis data, and for make these data available to everyone.

Funding Open Access funding provided thanks to the CRUE-CSIC agreement with Springer Nature. BA was supported by CajaSiete program for PhD students. This Project is financed by the European Union INTERREG MAC 2014-2020 Program (second call), co-funded by European Regional Development Fund (ERDF-FEDER).

\section{Declarations}

Conflict of interest The authors declare no competing interests.

Open Access This article is licensed under a Creative Commons Attribution 4.0 International License, which permits use, sharing, adaptation, distribution and reproduction in any medium or format, as long as you give appropriate credit to the original author(s) and the source, provide a link to the Creative Commons licence, and indicate if changes were made. The images or other third party material in this article are included in the article's Creative Commons licence, unless indicated otherwise in a credit line to the material. If material is not included in the article's Creative Commons licence and your intended use is not permitted by statutory regulation or exceeds the permitted use, you will need to obtain permission directly from the copyright holder. To view a copy of this licence, visit http://creativecommons.org/licenses/by/4.0/.

\section{References}

Andrews S, Bennett S, Wernberg T (2014). Reproductive seasonality and early life temperature sensitivity reflect vulnerability of a seaweed undergoing range reduction. Mar Ecol Prog Series 495:119-129. https://doi.org/10.3354/meps 10567

Alestra T, Schiel DR (2015) Impacts of local and global stressors in intertidal habitats: influence of altered nutrient, sediment and temperature levels on the early life history of three habitat-forming macroalgae. J Exp Mar Biol Ecol 468:29-36. https://doi.org/10. 1016/j.jembe.2015.03.017

Alfonso B, Sangil C, Sansón M (2017) Morphological and phenological reexamination of the threatened endemic species Gelidium canariense (Gelidiales, Rhodophyta) from the Canary Islands. Bot Mar 60:543-553. https://doi.org/10.1515/ bot-2017-0004

Alfonso B, Sangil C, Sansón M (2019) Gelidiales (Rhodophyta) in the Canary Islands: previous studies and future perspectives. Scientia Insularum 2:153-181. https://doi.org/10.25145/j.Si.2019.02.07

Álvarez-Losada Ó, Arrontes J, Martínez B, Fernández C, Viejo RM (2020) A regime shift in intertidal assemblages triggered by loss of algal canopies: A multidecadal survey. Mar Environ Res. https://doi.org/10.1016/j.marenvres.2020.104981

Anderson MJ, Gorley RN, Clarke KR (2008) PERMANOVA+ for PRIMER: guide to Software and Statistical Methods. PRIMERE: Plymouth, UK

Andrady AL, Aucamp PJ, Austin AT, Bais AF, Ballare CL et al (2017) Environmental effects of ozone depletion and its interactions with climate change: progress report, 2016. Photochem Photobiol Sci 16(2):107. https://doi.org/10.1039/C7PP90001E
Bais AF, McKenzie RL, Bernhard G, Aucamp PJ, Ilyas M et al (2015) Ozone depletion and climate change: impacts on UV radiation. Photochem Photobiol Sci 14(1):19-52. https://doi.org/10.1039/ C4PP90032D

Barnes PW, Williamson CE, Lucas RM, Robinson SA, Madronich S et al (2019) Ozone depletion, ultraviolet radiation, climate change and prospects for a sustainable future. Nat Sustain 2(7):569-579. https://doi.org/10.1038/s41893-019-0314-2

Barton ED, Arístegui J, Tett P, Cantón M, García-Braun J et al (1998) The transition zone of the Canary Current upwelling region. Prog Oceanogr 41(4):455-504. https://doi.org/10.1016/S00796611(98)00023-8

Bartsch I, Wiencke C, Laepple T (2012). Global seaweed biogeography under a changing climate: the prospected effects of temperature. In: Wiencke C, Bischof K (eds) Seaweed biology Springer, Berlin, Heidelberg. pp 383-406

Bertolini C (2019) Can secondary species maintain a primary role? Consistent inter-regional effects of understory algae on diversity. Mar Biodivers 49:841-849. https://doi.org/10.1007/ s12526-018-0862-0

Bischof K, Gomez I, Molis M, Hanelt D, Karsten U et al (2006) Ultraviolet radiation shapes seaweed communities. Rev Environ Sci Biotechnol 5(2-3):141-166. https://doi.org/10.1007/978-1-40206285-8_12

Bischof K, Hanelt D, Wiencke C (1998) UV-radiation can affect depthzonation of Antarctic macroalgae. Mar Biol 131(4):597-605. https://doi.org/10.1007/s002270050351

BOE (Boletín Oficial del Estado) (2019) Modificación del anexo del Real Decreto 139/2011 para el desarrollo del Listado de especies silvestres en régimen de protección especial y del Catálogo Español de especies amenazadas. Ministerio de Transición Ecológica, Gobierno de España 134:58611-58615

Borja A, Chust G, Fontan A, Garmendia JM, Uyarra MC (2018) Longterm decline of the canopy-forming algae Gelidium corneum, associated to extreme wave events and reduced sunlight hours, in the southeastern Bay of Biscay. Estuar Coast Shelf Sci 205:152160. https://doi.org/10.1016/j.ecss.2018.03.016

Both C, Van Asch M, Bijlsma RG, Van Den Burg AB, Visser ME (2009) Climate change and unequal phenological changes across four trophic levels: constraints or adaptations? J Anim Ecol 78(1):73-83. https://doi.org/10.1111/j.1365-2656.2008.01458.x

Broennimann O, Thuiller W, Hughes G, Midgley GF, Alkemade JR et al (2006) Do geographic distribution, niche property and life form explain plants' vulnerability to global change? Glob Change Biol 12(6):1079-1093. https://doi.org/10.1111/j.1365-2486.2006. 01157.x

Buchanan J, Zuccarello GC (2012) Decoupling of short-and longdistance dispersal pathways in the endemic New Zealand seaweed Carpophyllum maschalocarpum (Phaeophyceae, Fucales). J Phycol 48(3):518-529. https://doi.org/10.1111/j.1529-8817. 2012.01167.x

Buonomo R, Chefaoui RM, Lacida RB, Engelen AH, Serrão EA et al (2018) Predicted extinction of unique genetic diversity in marine forests of Cystoseira spp. Mar Environ Res 138:119-128. https:// doi.org/10.1016/j.marenvres.2018.04.013

Burrows MT, Schoeman DS, Buckley LB, Moore P, Poloczanska ES et al (2011) The pace of shifting climate in marine and terrestrial ecosystems. Science 334(6056):652-655. https://doi.org/10.1126/ science. 1210288

Capdevila P, Hereu B, Riera JL, Linares C (2016) Unravelling the natural dynamics and resilience patterns of underwater Mediterranean forests: insights from the demography of the brown alga Cystoseira zosteroides. J Ecol 104(6):1799-1808. https://doi.org/ 10.1111/1365-2745.12625

Capdevila P, Hereu B, Salguero-Gómez R, Rovira GL, Medrano A et al (2019) Warming impacts on early life stages increase the 
vulnerability and delay the population recovery of a long-lived habitat-forming macroalga. J Ecol 107(3):1129-1140. https://doi. org/10.1111/1365-2745.13090

Casado-Amezúa P, Araújo R, Bárbara I, Bermejo R, Borja A et al (2019) Distributional shifts of canopy-forming seaweeds from the Atlantic coast of Southern Europe. Biodivers Conserv 28(5):1151-1172. https://doi.org/10.1007/s10531-019-01716-9

Clark JS, Poore AG, Ralph PJ, Doblin MA (2013) Potential for adaptation in response to thermal stress in an intertidal macroalga. $\mathrm{J}$ Phycol 49(4):630-639. https://doi.org/10.1111/jpy.12067

Davison IR (1991) Environmental effects on algal photosynthesis: temperature. J Phycol 27(1):2-8. https://doi.org/10.1111/j.0022-3646. 1991.00002.x

Díez I, Muguerza N, Santolaria A, Ganzedo U, Gorostiaga JM (2012) Seaweed assemblage changes in the eastern Cantabrian Sea and their potential relationship to climate change. Estuar Coast Shelf Sci 99:108-120. https://doi.org/10.1016/j.ecss.2011.12.027

Domínguez-Álvarez S, Rico JM, Gil-Rodríguez MC (2011) Photosynthetic response and zonation of three species of Gelidiales from Tenerife, Canary Islands. Anales del Jardín Botánico de Madrid 68(1):117-124

Duarte L, Viejo RM, Martínez B, de Castro M, Gómez-Gesteira M et al (2013) Recent and historical range shifts of two canopy-forming seaweeds in North Spain and the link with trends in sea surface temperature. Acta Oecologica 51:1-10. https://doi.org/10.1007/ s10531-019-01716-9

Eggert A (2012) Seaweed responses to temperature. In: Wiencke C, Bischof K (eds) Seaweed biology. Ecological Studies (Analysis and Synthesis). Springer, Berlin, Heidelberg. pp, 47-66.

Flukes EB, Johnson CR, Wright JT (2014) Thinning of kelp canopy modifies understory assemblages: the importance of canopy density. Mar Ecol Prog Ser 514:57-70. https://doi.org/10.3354/meps1 0964

Gallardo T, Bárbara I, Afonso-Carrillo J, Bermejo R, Altamirano M et al (2016) Nueva lista crítica de las algas bentónicas marinas de España. Algas 51:7-52

Gaylord B, Reed DC, Raimondi PT, Washburn L (2006) Macroalgal spore dispersal in coastal environments: mechanistic insights revealed by theory and experiment. Ecol Monogr 76(4):481-502. https://doi.org/10.1890/0012-9615(2006)076[0481:MSDICE]2.0. $\mathrm{CO} ; 2$

Gaylord B, Reed DC, Raimondi PT, Washburn L, McLean SR (2002) A physically based model of macroalgal spore dispersal in the wave and current-dominated nearshore. Ecology 83:1239-1251. https:// doi.org/10.1890/0012-9658(2002)083[1239:APBMOM]2.0.CO;2

Guiry MD, Guiry GM (2020) AlgaeBase. World-wide electronic publication, National University of Ireland, Galway. https://www.algae base.org. Accessed on 1st January 2021

Häder DP (2018) Polar macroalgae. Aquatic ecosystems in a changing climate. CRC Press, Princeton

Häder DP, Helbling EW, Williamson CE, Worrest RC (2011) Effects of $\mathrm{UV}$ radiation on aquatic ecosystems and interactions with climate change. Photochem Photobiol Sci 10(2):242-260. https://doi.org/ 10.1039/c0pp90036b

Hawkins SJ, Sugden HE, Mieszkowska N, Moore PJ, Poloczanska E et al (2009) Consequences of climate-driven biodiversity changes for ecosystem functioning of North European rocky shores. Mar Ecol Prog Ser 396:245-259. https://doi.org/10.3354/meps08378

Hernández JC, Clemente S, Girard D, Pérez-Ruzafa A, Brito A (2010) Effect of temperature on settlement and post-settlement survival in barrens-forming sea urchin. Mar Ecol Prog Ser 413:69-80. https:// doi.org/10.3354/meps08684

Huovinen P, Gómez I (2013) Photosynthetic characteristics and UV stress tolerance of Antarctic seaweeds along the depth gradient. Polar Biol 36(9):1319-1332. https://doi.org/10.1007/ s00300-013-1351-3

Incagnone G, Marrone F, Barone R, Robba L, Naselli-Flores L (2015) How do freshwater organisms cross the "dry ocean"? A review on passive dispersal and colonization processes with a special focus on temporary ponds. Hydrobiologia 750(1):103-123. https://doi. org/10.1007/s10750-014-2110-3

Karsten U, Dummermuth A, Hoyer K, Wiencke C (2003). Interactive effects of ultraviolet radiation and salinity on the ecophysiology of two Arctic red algae from shallow waters. Polar Biol 26(4):249 258. https://doi.org/10.1007/s00300-002-0462-z

Kier G, Kreft H, Lee TM, Jetz W, Ibisch PL et al (2009) A global assessment of endemism and species richness across island and mainland regions. PNAS 106(23):9322-9327. https://doi.org/10. 1073/pnas.0810306106

La Sorte FA, Jetz W (2010) Projected range contractions of montane biodiversity under global warming. Proc R Soc Lond [biol] 277(1699):3401-3410. https://doi.org/10.1098/rspb.2010.0612

Lambers JHR (2015) Extinction risks from climate change. Science 348(6234):501-502. https://doi.org/10.1126/science.aab2057

Lang SI, Cornelissen JH, Shaver GR, Ahrens M, Callaghan TV et al (2012) Arctic warming on two continents has consistent negative effects on lichen diversity and mixed effects on bryophyte diversity. Glob Change Biol 18(3):1096-1107. https://doi.org/10. 1111/j.1365-2486.2011.02570.x

Littler MM, Littler DS (1980) The evolution of thallus form and survival strategies in benthic marine macroalgae: field and laboratory tests of a functional form model. Am Nat 116:25-44

Littler MM, Littler DS (2011) Algae, turf. In: D. Hopley (ed.) Encyclopedia of modern coral reefs: Structure, form and process. Encyclopedia of Earth Sciences Series. Berlin, Springer Dordrecht. https://doi.org/10.1007/978-90-481-2639-2_174

Malcolm JR, Markham A (2000) Global warming and terrestrial biodiversity decline. WWF, Washington, DC

Martín JL, Bethencourt J, Cuevas-Agulló E (2011). Evaluación del calentamiento global en Tenerife. Tendencias desde 1944 en las temperaturas máximas y mínimas anuales. Informe Técnico. Gobierno de Canarias, Agencia Canaria de desarrollo sostenible y cambio climático. $28 \mathrm{p}$.

Martínez B, Afonso-Carrillo J, Anadón R, Araújo R, Arenas F et al (2015) Regresión de las algas marinas en la costa atlántica de la Península Ibérica y en las Islas Canarias por efecto del cambio climático. Algas 49:5-12

Menéndez R (2007) How are insects responding to global warming? Tijdschrift Voor Entomologie 150(2):355

Mercado JM, Niell FX, Gil-Rodríguez MC (2001) Photosynthesis maybe limited by light, not inorganic carbon availability, in three intertidal Gelidiales species. New Phytol 149:431-439. https:// doi.org/10.1046/j.1469-8137.2001.00050.x

Mieszkowska N, Kendall MA, Hawkins SJ, Leaper R, Williamson P et al (2006) Changes in the range of some common rocky shore species in Britain - a response to climate change? Hydrobiologia 555:241-251. https://doi.org/10.1007/s10750-005-1120-6

Morueta-Holme N, Engemann K, Sandoval-Acuña P, Jonas JD, Segnitz RM et al (2015) Strong upslope shifts in Chimborazo's vegetation over two centuries since Humboldt. PNAS 112(41):12741-12745. https://doi.org/10.1073/pnas.1509938112

Muñoz E, Reyes J, Sansón M (2007) Descripción y cartografía de las comunidades bentónicas de Playa de San Marcos (Tenerife, islas Canarias). Vieraea 35:93-108

Myers N, Mittermeier RA, Mittermeier CG, Da Fonseca GA, Kent J (2000) Biodiversity hotspots for conservation priorities. Nature 403(6772):853. https://doi.org/10.1038/35002501 
Navarro NP, Huovinen P, Gómez I (2016) Stress tolerance of Antarctic macroalgae in the early life stages. Rev Chil Hist Nat 89(1):5. https://doi.org/10.1186/s40693-016-0051-0

Navarro NP, Huovinen P, Gómez I (2019) Photosynthetic characteristics of geographically disjunct seaweeds: a case study on the early life stages of Antarctic and Subantarctic species. Prog Oceanogr 174:28-36. https://doi.org/10.1016/j.pocean.2018.11.001

Nicastro KR, Zardi GI, Teixeira S, Neiva J, Serrão EA et al (2013) Shift happens: trailing edge contraction associated with recent warming trends threatens a distinct genetic lineage in the marine macroalga Fucus vesiculosus. BMC Biol 11(1):6. https://doi.org/ 10.1186/1741-7007-11-6

Norton TA (1992) Dispersal by Macroalgae British Phycol J 27(3):293301. https://doi.org/10.1080/00071619200650271

Parmesan C, Yohe G (2003) A globally coherent fingerprint of climate change impacts across natural systems. Nature 421(6918):37-42. https://doi.org/10.1038/nature01286

Payo DA, Leliaert F, Verbruggen H, D'hondt S, Calumpong HP et al (2012) Extensive cryptic species diversity and fine-scale endemism in the marine red alga Portieria in the Philippines. PNAS 280(1753):20122660. https://doi.org/10.1098/rspb.2012.2660

Pinedo S, Afonso-Carrillo J (1994) Distribución y zonación de las algas marinas bentónicas de Puerto de la Cruz, Tenerife (Islas Canarias). Vieraea 23:109-123

Piñeiro-Corbeira C, Barreiro R, Cremades J, Arenas F (2018) Seaweed assemblages under a climate change scenario: functional responses to temperature of eight intertidal seaweeds match recent abundance shifts. Sci Rep 8(1):1-9. https://doi.org/10.1038/ s41598-018-31357-x

Polifrone M, Gil-Rodríguez MC, Domínguez-Álvarez S, Stroobant M, Viera-Rodríguez MA (2012) Reproductive phenology of three species of Gelidiales (Rhodophyta) in two macroalgal communities from Tenerife (Atlantic Ocean, Canary Islands, Spain). Anales Jard Bot Madrid 69(2):247-252. https://doi.org/10.3989/ ajbm.2325

Quintano E, Díez I, Muguerza N, Figueroa FL, Gorostiaga JM (2017) Bed structure (frond bleaching, density and biomass) of the red alga Gelidium corneum under different irradiance levels. J Sea Res 130:180-188.

Rivetti I, Fraschetti S, Lionello P, Zambianchi E, Boero F (2014) Global warming and mass mortalities of benthic invertebrates in the Mediterranean Sea. PLoS ONE 9(12):e115655. https:// doi.org/10.1371/journal.pone.0115655

Rodríguez M, Pérez Ó, Monterroso Ó, Ramos E, Riera R et al (2008) Estudio de la distribución y tamaño de población de la especie Gelidium canariense (Grunow) Seoane Camba ex Haroun, GilRodríguez, Díaz de Castro and Prud'homme van Reine, 2002 en Canarias. C.I.M.A. Informe Técnico 31:1-96

Roleda MY, Wiencke C, Hanelt D, Bischof K (2007a) Sensitivity of the early life stages of macroalgae from the northern hemisphere to ultraviolet radiation. Photochem Photobiol 83(4):851-862. https:// doi.org/10.1562/2006-08-17-IR-1005

Roleda MY, Zacher K, Wulff A, Hanelt D, Wiencke C (2007b) Photosynthetic performance, DNA damage and repair in gametes of the endemic Antarctic brown alga Ascoseira mirabilis exposed to ultraviolet radiation. Austral Ecol 32(8):917-926. https://doi.org/ 10.1111/j.1442-9993.2007.01796.x

Root TL, Price JT, Hall KR, Schneider SH, Rosenzweig C et al (2003) Fingerprints of global warming on wild animals and plants. Nature 421(6918):57-60. https://doi.org/10.1038/natur e01333

Sangil C, Martins GM, Hernández JC, Alves F, Neto AI et al (2018) Shallow subtidal macroalgae in the North-eastern Atlantic archipelagos (Macaronesian region): a spatial approach to community structure. Eur J Phycol 53(1):83-98. https://doi.org/10. 1080/09670262.2017.1385098

Sangil C, Sansón M, Afonso-Carrillo J, Herrera R, Rodríguez A et al (2012) Changes in subtidal assemblages in a scenario of warming: proliferations of ephemeral benthic algae in the Canary Islands (eastern Atlantic Ocean). Mar Environ Res 77:120-128. https:// doi.org/10.1016/j.marenvres.2012.03.004

Sansón M, Reyes J, Afonso-Carrillo J (2001) Flora marina. In: Fernández-Palacios JM, Martín-Esquivel JL (eds) Naturaleza de las Islas Canarias: Ecología y Conservación. Santa Cruz de Tenerife: Ed. Turquesa. pp, 193-198.

Santelices B (1990) Patterns of reproduction, dispersal and recruitment in seaweeds. Oceanogr Mar Biol 28:177-276

Schiel DR, Lilley SA (2011) Impacts and negative feedbacks in community recovery over eight years following removal of habitatforming macroalgae. J Exp Mar Biol Ecol 407(1):108-115. https://doi.org/10.1016/j.jembe.2011.07.004

Schiel DR, Steinbeck JR, Foster MS (2004) Ten years of induced ocean warming causes comprehensive changes in marine benthic communities. Ecology 85(7):1833-1839. https://doi.org/10.1890/ 03-3107

Schmitz C, Ramlov F, de Lucena LAF, Uarrota V, Batista MB et al (2018) UVR and PAR absorbing compounds of marine brown macroalgae along a latitudinal gradient of the Brazilian coast. J Photochem Photobiol B 178:165-174. https://doi.org/10.1016/j. jphotobiol.2017.10.029

Shanks AL, Grantham BA, Carr MH (2003) Propagule dispersal distance and the size and spacing of marine reserves. Ecol Appl 13:159-169. https://doi.org/10.1890/1051-0761(2003)013[0159: PDDATS]2.0.CO;2

Smale DA, Wernberg T (2013) Extreme climatic event drives range contraction of a habitat-forming species. Proc Biol Sci 280(1754):20122829. https://doi.org/10.1098/rspb.2012.2829

Tanaka K, Taino S, Haraguchi H, Prendergast G, Hiraoka M (2012) Warming off southwestern Japan linked to distributional shifts of subtidal canopy-forming seaweeds. Ecol Evol 2(11):2854-2865. https://doi.org/10.1002/ece3.391

Thibaut T, Pinedo S, Torras X, Ballesteros E (2005) Long-term decline of the populations of Fucales (Cystoseira spp. and Sargassum spp.) in the Albères coast (France, North-western Mediterranean). Mar Pollut Bull 50(12):1472-1489. https://doi.org/10.1016/j. marpolbul.2005.06.014

Van Den Bogaard P (2013) The origin of the Canary Island Seamount Province-New ages of old seamounts. Sci Rep 3:2107. https://doi. org/10.1038/srep02107

Veron S, Haevermans T, Govaerts R, Mouchet M, Pellens R (2019) Distribution and relative age of endemism across islands worldwide. Sci Rep 9(1):1-12. https://doi.org/10.1038/s41598-019-47951-6

Wernberg T, Bennett S, Babcock RC, De Bettignies T, Cure K et al (2016) Climate-driven regime shift of a temperate marine ecosystem. Science 353(6295):169-172. https://doi.org/10.1126/scien ce.aad 8745

Wernberg T, Smale DA, Tuya F, Thomsen MS, Langlois TJ et al (2013) An extreme climatic event alters marine ecosystem structure in a global biodiversity hotspot. Nat Clim Change 3(1):78-82. https:// doi.org/10.1038/nclimate 1627

Wernberg T, Thomsen MS, Tuya F, Kendrick GA, Staehr PA et al (2010) Decreasing resilience of kelp beds along a latitudinal temperature gradient: potential implications for a warmer future. Ecol Lett 13(6):685-694. https://doi.org/10.1111/j.1461-0248. 2010.01466.x 
Whittaker RJ, Fernández-Palacios JM (2007) Island biogeography: ecology, evolution, and conservation. Oxford University Press, UK

Wiencke C, Amsler CD (2012) Seaweeds and their communities in polar regions. In: Wiencke C, Bischof K (eds) Seaweed Biology. Springer, Berlin, Heidelberg, pp 265-291

Wiencke C, Roleda MY, Gruber A, Clayton MN, Bischof K (2006) Susceptibility of zoospores to UV radiation determines upper depth distribution limit of Arctic kelps: evidence through field experiments. J Ecol 94:455-463. https://doi.org/10.1111/j.13652745.2006.01102.x

Wildpret W, Gil-Rodríguez MC, Afonso-Carrillo J (1987) Evaluación cuantitativa y cartografía de los campos de algas y praderas de fanerógamas marinas del litoral canario. Consejería de Agricultura y Pesca, Gobierno de Canarias. Informe técnico.
Wilmé L, Goodman SM, Ganzhorn JU (2006) Biogeographic Evolution of Madagascar's Microendemic Biota. Science 312:1063-1065. https://doi.org/10.1126/science.1122806

Publisher's note Springer Nature remains neutral with regard to jurisdictional claims in published maps and institutional affiliations. 